\title{
PENGEMBANGAN MEDIA PRAKTIK PENGELASAN MODEL SHIELDED METAL ARC WELDING (SMAW) MAHASISWA PROGRAM STUDI PENDIDIKAN TEKNIK OTOMOTIF UNIVERSITAS MUHAMMADIYAH PURWOREJO
}

\author{
Oleh : Tri Wahyudi, Ashari Pendidikan Teknik Otomotif Fakultas Keguruan dan IImu \\ Pendidikan Universitas Muhammadiyah Purworejo. \\ E-mail : triwahyudi150165@gmail.com,ashari.ump@gmail.com
}

\section{ABSTRAK}

Penelitian ini bertujuan untuk 1) Mengetahui prosedur pengembangan media praktik pengelasan. 2) Mengetahui kelayakan media praktik pengelasan terhadap kegiatan praktik mahasiswa Pendidikan Teknik Otomotif Universitas Muhammadiyah Purworejo. dan 3) Mengetahui pengaruh penggunaan media praktik pengelasan terhadap minat praktik pengelasan di bengkel mahasiswa Pendidikan Teknik Otomotif Universitas Muhammadiyah Purworejo.

Penelitian ini menggunakan metode Reseach and Development (R \& D) dengan subyek penelitian yang diambil adalah mahasiswa semester 7 Pendidikan Teknik Otomotif Universitas Muhammadiyah Purworejo yang bejumlah 20 mahasiswa. dengan sampel dua kelompok, yaitu kelompok A sebagai kelas kontrol dengan jumlah 10 mahasiswa dan kelas B sebagai kelas eksperimen dengan jumlah 10 mahasiswa. Pengumpulan data menggunakan metode kuesioner (angket) untuk mengetahui kelayakan media yang digunakan untuk penelitian. Uji analisis data menggunakan uji normalitas, uji homogenitas uji ttest.

Dari hasil penelitian, menunjukan bahwa Pengembangan Media Praktik Pengelasan Model SMAW dan yang menggunakan Pengembangan Media Praktik Pengelasan Model SMAW. Melalui uji normalitas perbandingan minat praktik kelas eksperimen dan kelas kontrol diperoleh $p=0,716$ (kelas eksperimen) dan $p=0,396$ (kelas kontrol), karena $p>0,05$ menunjukkan kedua kelompok berdistribusi normal., melalui uji homogenitas diperoleh $F_{\text {hitung }}=0,183$ dengan $p=0,674$. Karena $p>0,05$ menunjukkan kedua kelompok memiliki varian homogen., melalui uji t-tes hasilnya $t_{\text {hitung }}$ diperoleh $t$ hitung sebesar -157 dengan $\mathrm{p}=0,877>0,05$ menunjukkan tidak ada perbedaan minat praktik kelas eksperimen dan kelas kontrol, artinya rata-rata minat praktik kelas eksperimen dan kelas kontrol tidak terdapat perbedaan yang signifikan.

Kata Kunci : Media Praktik, Pengelasan Model SMAW, Minat Praktik 


\section{PENDAHULUAN}

Belajar adalah sesuatu yang terjadi di dalam benak seseorang, yaitu di dalam otaknya. (Dina Gasong, 2018: 8). Selain pendapat tersebut, Dina Gasong (2018: 9) menerangkan bahwa belajar adalah belajar itu terjadi terutama ketika seseorang merespon, dan menerima rangsangan dari lingkungan eksternal, maturasi hanya memerlukan pertumbuhan darii dalam.

Menurut Darmadi (2017:37). Minat merupakan suatu keadaan di mana seseorang mempunyai perhatian terhadap sesuatu dan disertai keinginan untuk mengetahui dan mempelajari maupun membuktikannya lebih lanjut. Minat timbul karena adanya perhatian yang mendalam terhadap suatu obyek, di mana perhatian tersebut menimbukan keinginan untuk mengetahui, mempelajari, serta membuktikan lebih lanjut. Hal ini menunjukan, bahwa dalam minat, di samping perhatian juga terkandung suatu usaha untuk mendapatkan sesuatu dari obyekk tersebut.

Media memiliki konotasi yang terlalu luas dan kompleks. Menurut Saetler 2004 dalam (muhammad yaumi 2018: 5). media (singuilar medium) berasal dari bahasa latin yang berarti antara dan perantara, yang merujuk pada sesuatu yang dapat menghubungkan informasi antara sumber dan penerima informasi. Menurut Smaldino, Lowther, dan Russel 2008 dalam (muhammad yaumi 2008: 5). Prihatin (2008: 50) menerangkan bahwa media adalah media yang dapat digunakan untuk membantu siswa di dalam memahami dan memperoleh informasi yang dapat didengar ataupun dilihat oleh panca indera sehingga pembelajaran dapat berhasil.

Media pembelajaran merupakan alat dan Bahan yang digunakan untuk mengefektifkan dan mengefisiensikan proses pembelajaran untuk mencapai tujuan pembelajaran (Satrianawati 2018: 8). Kata media berasal dari bahasa latin medium yang secara harfiah berarti perantara atau pengantar. Media adalah 
perantara antara pengantar pesan dari pengirim kepada penerima pesan (Azhar Arsyad 2011:3). Gerlach dan Ely (1971) yang dikutip Azhar Arsyad (2011:3), mengatakan bahwa media apabila dipahami secara garis besar adalah manusia, materi atau kejadian yang membangun kondisi yang membuat mahasiswa mampu memperoleh pengetahuan, keterampilan atau sikap. Dalam pengertian ini, dosen, buku, teks, dan lingkungan universitas merupakan media. Secara lebih khusus, pengertiian media dalam proses belajar mengajar cenderung diartikan sebagai alat-alat grafis, photografis, atau elektronis untuk menangkap, memproses, dan menyusun kembali informasi (pesan) visual atau verbal.

Dari pemaparan dari beberapa ahli di atas, dapat ditarik kesimpulan bahwa minat adalah kecenderungan dan ketertarikan yang tetap untuk memperhatikan atau terlibat terhadap sesuatu hal karena menyadari pentingnya atau bernilainya hal tersebut. Dengan demikian minat belajar dapat didefinisikan sebagai ketertarikan dan kecenderungan yang tetap untuk memperhatikan dan terlibat dalam aktifitas belajar karena menyadari pentingnya dan bernilainya hal yang dipelajari. Jika dikaitkan dengan aktifitas praktik atau pembelajaran di bengkel minat yaitu ketertarikan peserta didik dalam melakukan kegiatan dari awal sampai akhir dengan nyaman dan aman. Hal tersebut tentunya dapat tercapai jika sarana dan prasarana tersedia dan aman, serta lingkungan yang menyenangkan.

Permasalahan yang muncul di Universitas Muahammadiya Purworejo sebagai suatu permasalahan yang harus dicarikan alternatife solusi tindakan yang tepat, karena dengan masalah-masalah yang dihadapi mahasiswa dalam mengikuti kegiatan belajar akan menjadikan prestasi dan minat praktik mahasiswa cenderung menurun. Upaya yang dilakukan untuk meningkatkan minat praktik mahasiswa pada mata kuliah teknologi pembentukan dasar adalah dengan meningkatkan sarana prasarana penunjang kegiatan praktik pengelasan 
SMAW yang aman dan nyaman diharapkan proses pembelajaran lebih efektif sehingga mahasiswa lebih berminat praktik.

Berdasarkan fakta masalah yang telah diuraiakan diatas, maka peneliti merasa perlu adanya penelitian yang dapat mengukur perubahan minat praktik mahasiswa. Peneliti tertarik untuk melakukan penelitian dengan judul “Pengembangan Media Praktik Pengelasan Model Shielded Metal Arc Welding (SMAW) Mahasiswa Program Studi Pendidikan Teknik Otomotif Universitas Muhammadiyah Purworejo.".

Tujuan penelitian ini untuk : mengembangkan Media Praktik Pengelasan Model SMAW guna meningkatkan minat praktik mahasiswa pada mata kuliah teknologi pembentukan dasar di Universitas Muhammadiyah Purworejo, mengetahui kelayakan Media Praktik Pengelasan Model SMAW terhadap kegiatan penbelajaran mahasiswa Pendidikan Teknik Otomotif Universitas Muhammadiyah Purworejo, mengetahui pengaruh penggunaan media Praktik Pengelasan Model SMAW terhadap minat praktik mahasiswa Pendidikan Teknik Otomotif Universitas Muhammadiyah Purworejo.

\section{METODE PENELITIAN}

Jenis penelitian yang digunakan adalah penelitian dan pengembangan atau Research and Development, dengan melaksanakan 8 dari 10 langkah prosedur pengembangan. Penelitian ini dilaksanakan di Universitas Muhammadiyah Purworejo yang beralamat jl. K.H.A Dahlan 3 Purworejo. Waktu pelaksanaan penelitian ini pada bulan November 2019 sampai dengan Maret 2020. Subjek dalam penelitian ini adalah mahasiswa semester 7 Pendidikan Teknik Otomotif Universitas Muhammadiyah Purworejo tahun ajaran 2019/2020 yang berjumlah 20 mahasiswa yang telah menempuh mata kuliah pembentukan dasar otomotif. Data yang digunakan dalam penelitian ini diperoleh melalui metode kuesioner (angket).

Jurnal Pendidikan Teknik Otomotif_Universitas Muhammadiyah Purworejo 
Instrumen yang digunakan pada penelitian ini meliputi instrument tanggapan ahli media, tanggapan ahli materi, tanggapan mahasiswa. Instrumen pengumpulan data yaitu menggunakan kuesioner (angket). Jenis data penelitian ini adalah menggunakan data kuantitatif, kemudian data dianalisis secara statistik deskriptif. Uji prasyarat analisis data menggunakan uji normalitas, uji homogenitas, uji t-test.

\section{HASIL PENELITIAN DAN PEMBAHASAN}

Penelitian ini menunjukan adanya perbedaan pengaruh Praktik Pengelasan Model SMAW terhadap peningkatan minat praktik pada mahasiswa semester 7 pendidikan teknik otomotif Universitas Muhammadiyah Purworejo tahun ajaran 2019-2020.

Tabel Perbandingan Minat praktik Kelas Eksperimen dan Kelas Kontrol

\begin{tabular}{|l|c|c|}
\hline \multicolumn{1}{|c|}{ Indikator Statistik } & Kelas Kontrol & Kelas Eksperimen \\
\hline Jumlah & 296 & 297 \\
\hline Rata-rata & 29.60 & 29.70 \\
\hline Skor Tertinggi & 33 & 33 \\
\hline Skor Terendah & 28 & 28 \\
\hline Standar Deviasi & 1.350 & 1.494 \\
\hline Modus & 29 & 29 \\
\hline Median & 29.00 & 29.50 \\
\hline N & 10 & 10 \\
\hline
\end{tabular}


Tabel Hasil Uji T-test untuk Data Motivasi Belajar Menggunakan SPSS

\section{Independent Samples Test}

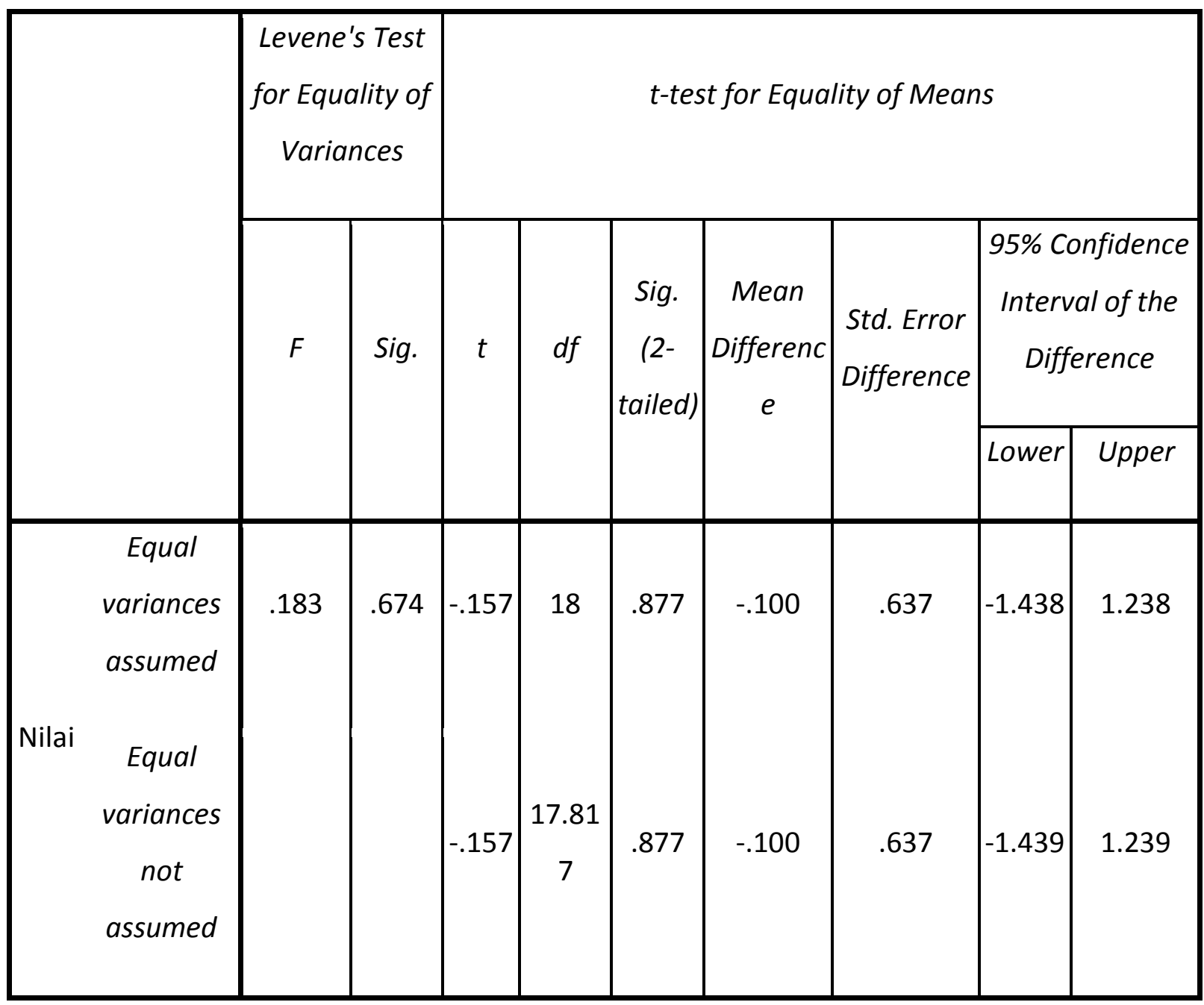

Hasil uji T perbandingan hasil belajar kelas eksperimen dan kelas kontrol diperoleh $t$ hitung sebesar -157 dengan $p=0,877>0,05$ menunjukkan tidak ada perbedaan minat praktik kelas eksperimen dan kelas kontrol, artinya rata-rata minat praktik kelas eksperimen dan kelas kontrol tidak terdapat perbedaan yang signifikan. Namun secara umum rata - rata minat praktik kelas eksperimen lebih tinggi dibandingkan kelas kontrol. 


\section{SIMPULAN DAN SARAN}

Dari hasil penelitian dan pengembangan ini, maka dapat disimpulkan adalah sebagai berikut :

1. Tahap pengembangan media pembelajaran sistem pengapian pada mahasiswa semester 7 Pendidikan Teknik Otomotif Universitas Muhammadiyah Purworejo telah meliputi pencarian potensi masalah, pengumpulan data, desain produk, validasi desain, revisi desain, uji coba produk, revisi produk, uji coba pemakaian

2. Hasil validasi produk oleh ahli materi 3,6 (sangat baik), ahli media 3,00 (baik), uji coba kelompok kecil 2.96 (baik), dan uji coba pemakaian produk 2,96 (baik). Dari hasil penilaian tersebut menunjukkan produk layak (baik) digunakan sebagai media pembelajaran.

3. Hasil uji t membuktikan bahwa media pembelajaran yang dibuat efektif untuk meningkatkan motivasi belajar ( $t_{\text {hitung }}=-157$ dan $p=0,877$ ) mahasiswa semester 7 Pendidikan Teknik Otomotif Universitas Muhammadiyah Purworejo. Media pembelajaran dapat digunakan dalam pembelajaran sebagai media untuk meningkatkan minat praktik karena dalam uji coba kelompok besar dengan jumlah mahasiswa 20 orang telah berhasil meningkatkan minat praktik mahasiswa.

Agar produk yang dihasilkan bisa dimanfaatkan secara maksimal dalam kegiatan pembelajaran, maka ada beberapa saran yang terkait dengan media praktik pengelasan SMAW antara lain :

1. Bagi Perguruan Tinggi

Diharapkan media pembelajaran ini dapat digunakan sebagai dasar pertimbangan di lembaga pendidikan untuk merumuskan kebijakan 
2. Bagi Mahasiswa

a) Melalui penelitian ini diharapkan media praktik pengelasan dapat lebih berkembang.

b) Dengan adanya media praktik pengelasan diharapkan kegiatan prakik lebih aman dan hasil praktik lebih baik.

\section{DAFTAR PUSTAKA}

Arsyad,Azhar. 2011. Media Pembelajaran. Jakarta: PT Raja Grafindo Persada

Darmadi.2017. pengembangan Model Metode Pembelajaran Dalam Dinamika Belajar Siswa. Yogyakarta: CV Budi Utama.

Gasong Dina. 2018. Belajar dan Pembelajaran. Yogyakarta: CV Budi Utama.

Yaumi muhammad. 2018. Media dan Teknologi Pembelajaran. Jakarta: Prenadamedia.

Satrianawati. 2018. Media dan Sumber Belajar. Yogyakarta: CV Budi Utama.

Sugiyono. 2015. Metode Penelitian Pendidikan. Bandung: Alfabeta. 


\section{STUDI TENTANG LAYANAN INDUSTRI OTOMOTIF TERHADAP PESERTA PRAKTIK KERJA INDUSTRI}

Oleh : Taufiqurrahman, Dwi Jatmoko Pendidikan Teknik Otomotif Fakultas Keguruan
dan Ilmu Pendidikan Universitas Muhammadiyah Purworejo.
E-mail : leopardcruiser99@gmail.com, dwijatmoko@umpwr.ac.id

ABSTRAK

Penelitian ini bertujuan untuk mengetahui, (1) Kompetensi produktif yang dapat diimplementasikan dalam kegiatan Praktik Kerja Industri (Prakerin) dan (2) untuk mengetahui bagaimana bentuk-bentuk partisipasi industri dalam pelaksanaan Prakerin Program Studi Pendidikan Teknik Otomotif.

Penelitian ini menggunakan pendekatan penelitian Ex-Post Facto. Penelitian ini merupakan penelitian deskriptif karena menggambarkan secara sistematis fakta dan karakteristik subjek yang diteliti secara tepat, kemudian memaparkannya secara lugas seperti apa adanya. Populasi pada penelitian ini adalah seluruh industri mitra kerjasama Prakerin program studi Pendidikan Teknik Otomotif U M P berjumlah 17 Industri di DIY dan Kabupaten Purworejo. Metode pengambilan data menggunakan angket/kuisioner semi-terbuka dan dokumentasi. Teknik analisis yang digunakan adalah analisis deskriptif kuantitatif dengan persentase dan analisis deskriptif kualitatif dengan penjelasan.

Hasil penelitian didapatkan bahwa: (1) Pekerjaan-pekerjaan yang diberikan oleh Industri merupakan kompetensi produktif yang telah diajarkan disekolah, intensitas pelaksanaannya di setiap Industri berbeda-beda mengacu pada layanan yang dimiliki oleh industri dan sumber daya yang dimiliki oleh Industri. (2) Partisipasi industri tidak bisa ditentukan berdasarkan kebutuhan dunia pendidikan khususnya sekolah, melainkan pihak sekolah yang harus melakukan pendekatan-pendekatan yang lebih intensif agar diperoleh kemitraan dengan industri yang lebih baik sehingga kebutuhan sekolah terhadap dunia industri sebagai tempat pembelajaran yang nyata dapat terlaksana. Industri telah memberikan partisipasinya bagi peserta didik berupa suatu wawasan baru dalam pembentukan karakter dan sikap peserta didik melaksanakan pekerjaan. Partisipasi Industri dalam membentuk karakter peserta didik tersebut berupa sikap disiplin dalam bekerja, inisatif dalam pekerjaan, kerjasama dan tanggungjawab dalam pekerjaan.

Kata kunci: Studi Layanan, Industri Otomotif, Prakerind 


\section{PENDAHULUAN}

Perkembangan ilmu pengetahuan dan teknologi yang pesat menimbulkan persaingan dalam dunia industri semakin ketat, untuk menjaga eksistensi proses produksi ataupun pelayanan jasa dalam suatu perusahaan menuntut sumber daya manusia yang berkualitas. Sumber daya manusia sebagai pencipta dan pengembang serta pemakai teknologi harus selalu berinovasi untuk meningkatkan kompetensi kerja serta ketrampilan professional agar dapat mempertahankan keberadaan suatu ilmu pengetahuan dan teknologi. Pemenuhan kebutuhan man power untuk mempersiapkan dan mengelola suatu kegiatan produksi ataupun jasa pelayanan yang berorientasi pada konsumen harus selalu dilakukan secara terus menerus, tanpa terkecuali manusia Indonesia. Indonesia hatus siap menghadapi persaingan global dalam memperoleh kesempatan untuk mengisi dan menggunakan serta meningkatkan keberadaan ilmu pengetahuan dan teknologi terutama dalam bidang otomotif.

Melalui pendidikan, maka peluang untuk mempersiapkan tenaga kerja tetap terbuka. Dengan pendidikan, sumber daya manusia, baik melalui pendidikan ataupun latihan secara teoritis maupun praktis baik dilaksanakan di kampus maupun belajar secara langsung di Industri sehingga diharapkan para lulusan dapat langsung mendapatkan lingkungan kerja yang sesuai dengan disiplin ilmu dan kompetensinya. Dengan ini maka pandangan sebagai graduate man participate to the increase unemployement dapat dihilangkan. Selain itu juga suatu langkah untuk penyesuaian suplay dan demand dalam ketenagakerjaan antara dunia pendidikan dengan dunia industri sesuai dengan kebijakan departemen Pendidikan Nasional dalam model pendidikan link and match. Universitas Muhammadiyah Purworejo melalui salah satu fakultasnya yaitu Fakultas Keguruan dan IImu Pendidikan program studi Pendidikan Teknik 
Otomotif termotivasi untuk mempersiapkan sumber daya manusia. Dalam memperoleh kecakapan serta kemampuan kognitif, afektif, dan psikomotorik dalam bidang otomotif maka mahasiswa harus menempuh mata kuliah wajib lulus yaitu mata kuliah Praktik Industri. Mata kuliah ini merupakan program kurikuler berbobot 3 SKS lapangan atau setara dengan 256 jam. Persyaratan mengambil mata kuliah Praktik Industri untuk jenjang S1 90 sks. Proses perkuliahan Praktik Industri bertujuan untuk mendekatkan serta mengaplikasikan ilmu pengetahuan yang didapat dalam bangku perkuliahan, baik teoritis maupun praktis pada dunia kerja sesungguhnya sehingga dapat mengeliminasi beberapa perbedaan dan kesenjangan antara dunia kampus dengan dunia kerja secara nyata.

\section{METODE PENELITIAN}

Penelitian ini bertujuan untuk mendapatkan data-data mengenai partisipasi industri dalam program Praktik Kerja Industri mulai dari tahap Perencanaan, tahap pelaksanaan dan tahap evaluasi. Berdasarkan data tersebut dapat diketahui kompetensi produktif yang terlaksana selama melakukan Praktik Kerja Industri dan bagaimana partisipasi industri dalam pelaksanaan Praktik Kerja Industri sehingga tujuan yang diharapkan dalam pelaksanaan Praktik Kerja Industri tercapai.

Penelitian ini menggunakan pendekatan penelitian Ex-Post Facto, karena dalam penelitian ini tidak dibuat perlakuan terhadap variabel-variabel penelitian. Penelitian ini hanya meneliti apa yang udah ada pada diri responden. Penelitian Ex-Post Facto merupakan penelitian dimana variabel-variabel bebas telah terjadi ketika peneliti mulai dengan pengamatan variabel terikat dalam penelitian. Penelitian ini juga sering disebut after the fact atau sesudah fakta dan ada pula peneliti yang menyebutkan sebagai retrospective study atau studi penelusuran kembali. 
Penelitian ini merupakan penelitian deskriptif. Penelitian deskriptif pada umumnya bertujuan untuk menggambarkan secara sistematis fakta dan karakteristik objek dan subjek yang diteliti secara tepat. Hal tersebut sejalan dengan Suharsimi Arikunto (2010:3) yang mengatakan bahwa pada penelitian deskriptif, peneliti hanya memotret apa yang terjadi pada diri obyek atau wilayah yang diteliti, kemudian memaparkannya secara lugas seperti apa adanya, penelitian ini menggunakan data kuantitatif.

Penelitian ini dilakukan di industri tempat peserta didik melakukan Praktik Kerja Industri yang tersebar di Kabupaten Purworejo dan Yogyakarta. Waktu penelitian dilaksanakan mulai bulan November 2018 sampai dengan selesai.

\section{HASIL PENELITIAN DAN PEMBAHASAN}

Berdasarkan jawaban yang diperoleh melalui penyebaran kepada 17 industri tempat melaksanakan prakerin yang dijadikan sebagai didapatkan data tentang layanan industri otomotif terhadap peserta praktik kerja industri Universitas Muhammadiyah Purworejo. Sebelum dilakukan analisis terlebih dilakukan uji validitas dan reliabilitas terhadap data yang diperoleh. Uji validitas menggunakan analisis korelasi point biserial untuk mengetahui validitas butir instrumen, hal ini untuk mengetahui adanya butir yang tidak valid setelah instrumen digunakan mengambil data. Setelah melakukan uji validitas instrumen, langkah selanjutnya yaitu menguji reliabelitas instrumen. Reliabilitas instrument penelitan merupakan keajegan dan kestabilan instrumen dalam mengukur aspek yang diukur (Eko Putro W, 2012:156). Uji reliabilitas instrumen menggunakan teknik Kuder dan Richardson (K-R20). 
Berikut ini disajikan ringkasan uji validitas dan uji reliabilitas

Ringkasan Uji Validitas

\begin{tabular}{|l|c|c|c|}
\hline \multicolumn{1}{|c|}{ Instrumen } & $\begin{array}{c}\text { Jumlah } \\
\text { Butir }\end{array}$ & $\begin{array}{c}\text { Jumlah } \\
\text { Butir } \\
\text { Valid }\end{array}$ & $\begin{array}{c}\text { Jumlah Butir } \\
\text { Tidak Valid }\end{array}$ \\
\hline Partisipasi Industri Otomotif & 19 & 17 & $2(13,16)$ \\
\hline Kompetensi Kejuruan & 11 & 11 & - \\
\hline Kompetensi Engine & 15 & 13 & $2(7,14)$ \\
\hline Pemindah Tenaga & 14 & 2 & $2(6,13)$ \\
\hline Chasis dan Suspensi & 8 & 8 & - \\
\hline Kelistrikan & 12 & 10 & $2(7,9)$ \\
\hline
\end{tabular}

Partisipasi Industri terhadap pelaksanaan Praktik Kerja Industri

\begin{tabular}{|c|c|c|r|r|}
\hline No & $\begin{array}{c}\text { Kelompok Partisipasi } \\
\text { dalam Prakerin }\end{array}$ & $\begin{array}{c}\text { Jumlah Rata- } \\
\text { rata Industri }\end{array}$ & Persentase & Kategori \\
\hline 1 & Tahap Perencanaan & 14.50 & 80.56 & Baik \\
\hline 2 & Tahap pelaksanaan & 14.63 & 81.25 & Baik \\
\hline 3 & Tahap Evaluasi & 14.67 & 81.48 & Baik \\
\hline \multicolumn{7}{|c|}{17} & \\
\hline
\end{tabular}

Universitas Muhammadiyah Purworejo khusunya program studi pendidikan teknik otomotif merupakan lembaga pendidikan tinggi yang mengutamakan penyiapan mahasiswanya agar memiliki kecakapan hidup (life skill) untuk memasuki lapangan kerja sesuai dengan bidangnya. Definisi ini didasarkan pada Undang-Undang SISDIKNAS yang menyatakan bahwa pendidikan menengah kejuruan merupakan pendidikan yang menyiapkan mahasiswanya agar siap bekerja dalam bidang tertentu. Berdasarkan hal tersebut, pemerintah melalui Depdiknas telah mengambil langkah-langkah penyelarasan dengan dunia Industri yang dikenal dengan istilah 12 kebijakan/prinsip Dikmenjur (Kurikulum 1993). Prinsip/Kebijakan Dikmenjur tersebut salah satunya yaitu program Link and Match yang dijalankan melalui 
Program Pendidikan Sistem Ganda dan dikenal dengan Praktik Kerja Industri (Praktik Kerja Industri).

Landasan tersebut mengharuskan universitas menjalin kerjasama yang erat dengan dunia usaha untuk membangun kemitraan yang sifatnya memberi manfaat antara kedua belah pihak. Kerjasama tersebut tidak hanya penting untuk dilakukan universitas kejuruan, tetapi sudah merupakan keharusan dan bahkan merupakan persyaratan bagi penyelenggaraan pendidikan kejuruan.

Penelitian partisipasi industri dalam implementasi kompetensi produktif terhadap pelaksanaan prakerin ini merupakan salah satu bentuk untuk mengetahui kompetensi produktif yang dilaksanakan dalam kegiatan Praktik Kerja Industri, dan bagaimana bentuk partisipasi industri dalam Pelaksanaan Praktik Kerja Industri Program Studi Pendidikan Teknik Otomotif Universitas Muhammadiyah Purworejo.

\section{KESIMPULAN}

Kompetensi produktif yang dilaksanakan dalam kegiatan praktik kerja meliputi:

1. Kompetensi produktif yang dapat diimplementasikan dalam pelaksanaan Praktik Kerja Industri berdasarkan pekerjaan-pekerjaan yang diberikan di industri merupakan kompetensi dasar yang umumnya sudah dipraktikkan di kampus. Hal ini menyebabkan tidak terlihat adanya pengembanganpengembangan dalam implementasinya. Kompetensi yang terlaksana tersebut berupa dasar kompetensi kejuruan dengan rerata kelompok sebesar $81,83 \%$ dalam implementasinya, kelompok kompetensi bidang engine dengan $80,77 \%$ dalam implementasinya. pada kelompok kompetensi sistem pemindah tenaga $82,41 \%$ dalam implementasinya, sedangkan kelompok kompetensi chasis dan suspensi dalam implementasinya diperoleh nilai rerata kelompok sebesar 80,56 dan kelompok kompetensi bidang 
kelistrikan didapatkan nilai rerata kelompok 82,22\%). Dengan demikian dapat ditarik kesimpulan bahwa kompetensi produktif yang terlaksana dalam pelaksanaan Praktik Kerja Industri secara keseluruhan rata-rata sebesar $81,49 \%$ dari total keseluruhan butir kompetensi.

2. Pekerjaan-pekerjaan yang diberikan oleh Industri merupakan komptensi produktif yang telah diajarkan di kampus intensitas pelaksanaannya di setiap industri berbeda-beda mengacu pada layanan yang dimiliki oleh industri dan sumber daya yang dimiliki oleh Industri Otomotif.

Bentuk Partispasi Industri dalam Pelaksanaan Praktek Kerja Industri didapatkan kesimpulan sebagai berikut:

1. Hasil Partispasi Industri dalam Pelaksanaan Praktek Kerja Industri sebanyak 80,56\% memberikan partisipasinya dalam tahap perencanaan. Sejumlah $81,25 \%$ memberikan partisipasinya dalam tahap pelaksanaan Praktik Kerja Industri. Sedangkan partisipasi industri dalam tahap evaluasi pelaksanaan Praktik Kerja Industri sejumlah $81.25 \%$ yang memberikan partisipasinya.

2. Industri telah memberikan partisipasinya bagi peserta didik berupa suatu wawasan baru sebagai pembentukan karakter dan sikap peserta didik dalam melakukan pekerjaan.

3. Partisipasi Industri dalam membentuk karakter peserta didik tersebut berupa sikap disiplin dalam bekerja, inisiatif dalam pekerjaan, kerjasama dan tanggung jawab dalam pekerjaan.

\section{SARAN}

Agar tujuan pelaksanaan Prakerin dapat tercapai lebih maksimal dan terdapat kesepadanan dan keterkaitan antara kompetensi yang dimiliki dengan pekerjaan yang diberikan oleh industri diperlukan usaha timbal balik antara pihak industri dengan pihak universitas, untuk itu disarankan sebagai berikut: 
1. Pihak Prodi Pendidikan Teknik Otomotif Universitas Muhammadiyah Purworejo seharusnya lebih aktif melakukan pendekatan-pendekatan dengan dunia industri agar terjalin koordinasi yang lebih baik sehingga program-program sekolah dapat terlaksana lebih maksimal

2. Hendaknya pihak program studi Pendidikan Teknik Otomotif Universitas Muhammadiyah Purworejo mempertimbangkan kapasitas dan daya dukung yang dimiliki oleh industri agar dalam pelaksanaan Prakerin tujuan yang diharapkan tercapai dengan maksimal tidak hanya dari kuantitas pelaksanaan tetapi juga kualitas hasil pelaksanaan

3. Diperlukan penelitian yang lebih mendalam terhadap kesiapan pelaksanaan Prakerin oleh Program Studi Pendidikan Teknik Otomotif Universitas Muhammadiyah Purworejo dan partisipasi industri dalam pelaksanaan Prakerin guna mengungkap permasalahan-permasalahan yang menghambat program tersebut.

\section{DAFTAR PUSTAKA}

Sutiman. (1997). Partisipasi Industri Otomotif Di Daerah Eks Kresidenan Banyumas Terhadap Kebijakan Link and Match. Abstrak Hasil Penelitian IKIP Yogyakarta. Yogyakarta. Lembaga Penelitian IKIP.

Suharsimi Arikunto. (2002). Prosedur Penelitian Suatu Pendekatan Praktek. Jakarta. Rineka Cipta.

Suharsimi Arikunto. (2013). Manajemen Penelitian. Jakarta. Rineka Cipta

Sugiyono (2009). Metode penelitian kauntitatif, kualitatif dan $R \& D$. Bandung. Alfabeta.

Sutrisno Hadi. (1984). Metode Research. Yogyakarta. Fakultas Psikologi Universitas Gadjah Mada. 